\title{
Sequences in Financial Liberalization in the Emerging-Market Economies: Growth, Volatility or Both?
}

\author{
Dilip K. Das
}

\begin{abstract}
The objective of this paper is to in-depth study the financial liberalization process in the various segments of the emerging-market economies and observe whether the resulting assertion of fast-clip real GDP growth holds. The author examines financial and macroeconomic turbulence in the emerging market economies during the 1990s and early 2000s, which gave a new perspective to the financial liberalization process. It was believed that capital account liberalization led to volatility in the capital market as well as macroeconomic volatility, which in turn led to a support for the strategy of restrictive global capital flows. The unrestricted trans-border capital flows were blamed for disorderly, if on occasion totally erratic, capital market behavior, both domestically and globally. After taking a long-term perspective on financial repression and financial liberalization, the author focuses on the liberalization-growth nexus. Capital account liberalization and whether it leads to growth and/or volatility or both are the issues are the next point of analyses. Relatively recent phenomenon of liberalization in equity markets, its pace and intensity, has also been delved into. Whether the recent spate of emerging-market crises bore a relationship with the financial liberalization is the other focus of this paper.
\end{abstract}

- JEL Classification: F02, F21, F32, F36

- Keywords: Financial liberalization, International capital flows, emergingmarkets, Growth, Volatility

\footnotetext{
*Corresponding address: Dilip K. Das Ph.D., Suite 505, Meadowvale Gardens 1, 2869 Battleford Road, Mississiauga, Ontario L5N 2S6, Canada, Tel: (+)1 905286 1264, E-mail: dilip.das@sympatico.ca (C)2004-Center for International Economics, Sejong Institution, All Rights Reserved.
} 


\section{Introduction}

When the post-World War II era began, the strategy of financial repression was endemic, leading to inefficient capital allocation and languished financial intermediation. A group of developing economies adopted gradual financial liberalization seriously and succeeded in turning into what became known as the emerging-market economies, a rapidly globalizing group of economies. The final outcome was more rapid real growth than in the past and also compared to the non-globalizing group of economies. The flip side of this coin is that in the recent past liberalization was squarely blamed for strong bouts of volatility in the emerging-market economies.

The objectives of this paper are to study the financial liberalization process in the various segments of the emerging-market economies and observe whether the resulting assertion of fast-clip real GDP growth holds. The financial and macroeconomic turbulence in the emerging market economies during the 1990s and early 2000s, which gave a new perspective to the financial liberalization process, has been elaborated in a detailed manner. It was believed that capital account liberalization led to volatility in the capital market as well as macroeconomic volatility, which in turn led to a support for the strategy of restrictive global capital flows. The unrestricted trans-border capital flows were blamed for disorderly, if on occasion totally erratic, capital market behavior, both domestically and globally. Whether the recent spate of emerging-market crises had a relationship with the financial liberalization is the other focus of this paper.

The structure of the paper is as follows. In Section 2, I focus on the liberalization-growth nexus. Capital account liberalization and whether it leads to growth and/or volatility or both are the issues on which Sections 3 and 4 dwell. Relatively recent phenomenon of liberalization in equity markets, its pace and intensity, has been delved into in Section 5. How they contributed to the recent rise in financial market and macroeconomic volatility in the emerging markets has also been discussed in Section 6. The last section briefly sums up the principal conclusions of the paper.

\section{Financial Liberalization and Growth Nexus}

Effects of controls on financial markets, capital flows and economic growth have been a prolific area of empirical research in international economics. 
Researchers in economic growth have also addressed the issue of financial liberalization and development of financial sector. Whether it has contributed to fast-clip growth in the emerging-market economies is an important, albeit difficult, question to answer. Although researchers in several disciplines have studied the financial liberalization-economic growth nexus both theoretically and empirically, there is no categorical conclusion regarding the contributions of financial liberalization to economic growth in the emerging-market economies. Neither theory provides a clear answer regarding how liberalization impacts growth nor do empirical studies. Many of these studies remained inconclusive. ${ }^{1}$ Most researchers have tended to focus on the effects of deregulation over domestic financial markets, like the stock markets and banking sector. Besides, subsumed into financial liberalization is the issue of capital account liberalization per se. It has remained a controversial policy measure and its effect has been little understood, although long debated. While several attempts were made, measuring its impact has remained a problem-ridden task. ${ }^{2}$

There are four important causes behind this disappointing state of affairs. The first hurdle was the lack of homogeneous measures of financial liberalization policies across countries and across time. ${ }^{3}$ Second, while several empirical studies were attempted, in general their scope was limited. They focused on one kind of reform measures, or elimination of controls on one particular financial market. Some concentrated on the elimination of controls on the banking sector, others on stock markets, and yet others focused narrowly on capital account liberalization. However, as noted above, financial repression can take many forms. Restrictive measures on one market not only affect it directly but also the other financial markets indirectly. As expected, narrowly focused studies produced inadequate and incomplete evaluation of the effects of financial liberalization.

Third, the problem of omitted variables is to be found in almost all empirical studies. Financial liberalization is seldom adopted as a solitary or exclusive policy measure. This policy measure is generally a part of a comprehensive liberalization policy package and includes measures like trade liberalization, improved

\footnotetext{
${ }^{1}$ Williamson and Mahar (1998) provide a detailed survey of financial liberalization endeavors.

${ }^{2}$ Rajan and Zingales (1998) and Eichengreen (2002) provide a literature survey of the empirical studies that attempt to quantify the growth impact of capital account liberalization.

${ }^{3}$ This was a common weakness of empirical studies, although Kaminsky and Schmukler (2001) did manage to develop a homogeneous dataset for several dimensions of financial liberalization.
} 
investment policies, privatization and strengthening of private property rights. Sachs and Warner (1997) emphasized that policy choices in these areas are important determinants of long-term growth. Therefore, to calculate the impact of financial liberalization on economic growth it is vitally important to controls for all the other reform measures that were adopted as a part of the larger policy package. Lastly, in addition to these shortcomings, Eichengreen (2002) pointed out that each emerging-market economies is sui generis. Each one has different macroeconomic, financial and political traits. Additionally, each economy has its idiosyncratic institutional strengths and weaknesses. While quantifying the growth impact of financial liberalization, these differences must be taken into account. A lack of this perspective, further adds to the difficulties of the empirical studies as well as puts a question mark on the acceptability of their conclusions.

Models based on perfect market assumptions tend to conclude that liberalization has welfare-inducing implications for market participants, both lenders and borrowers. Well-known theories posited by McKinnon (1973) and Shaw (1973) as well as others have pointed out that welfare enhancing effects of financial liberalization can work through interest rate mechanism. In a liberalized regime, the interest rates rise (or fall) to their competitive market equilibrium level, which leads to efficient allocation of productive resources. The second channel of welfare gains could work through capital account liberalization. Third, in a developing economy setting, it is not inappropriate to assume that financial markets are imperfect and that capital constraints are endemic (Hubbard, 1998). Given these circumstances, external finance will be typically more expensive than domestic finance, which in turn would make the rate of domestic investment sensitive to external capital flows. In such developing economies, if equity markets are liberalized, one of the direct effects should be easing of capital constraint because more global capital can flow in. A possible indirect effect would be improvement in the quality of corporate governance. Improvement in corporate governance is sure to lead to improvement in risk sharing. Together these two effects should force the cost of capital down.

Among the financial economists, Goldsmith (1969) was the first to address the issue of growth impact of financial liberalization, followed by seminal contributions of McKinnon (1973) and Shaw (1973). Their proposition regarding this relationship was simple and positive. They concurred that liberalization favorably affects economic growth by, first, strengthening the size and improving the efficiency of the domestic financial system, second, by allowing domestic firms 
to access the global financial markets, and third, by improving the level of corporate governance in the domestic financial system and thereby reducing the agency problems. The focus of McKinnon (1973) and Shaw (1973) was also the advantages of reducing financial repression prevalent during their period. They pointed out among advantages of reducing financial restrictions included higher savings rates, improved allocation of resources and a lack of compulsion to adopt dualistic growth policies.

Inclusion of static and dynamic factors subsequently refined this scenario. Financial liberalization promotes foreign competition in the domestic banking and non-banking financial sectors, reducing cost of capital. It allows the financial institutions in the emerging-market economies to adopt the newest financial know how, instruments, products and technologies. Financial deregulation and reforms fuel institutional reforms. Additionally, when domestic firms begin accessing the global capital market, their cost of capital declines and raises the level of domestic investment. There can be little doubt that there are static and dynamic impacts of these developments as well, which in turn buttress GDP growth rate. ${ }^{4}$ As firms begin to tap global capital and securities markets, a large font of capital and stockholder base becomes available to them. Domestic financial constraints are eased by the availability of greater quantum of capital (Gilchrist and Himmelberg, 1998).

In addition, there is an important indirect effect. Capital allocation by markets putatively improves the efficiency of allocation and financial resources head for sectors having comparative advantage that were constrained during the period of financial repression (Sarkissian and Schill, 2001). A good deal of evidence of these static and dynamic effects was provided by several emerging-market economies. The liberalized emerging markets came to have an opportunity to grow and develop like their counterparts in the advanced industrial economies.

Recent studies have supported what McKinnon and Shaw posited three decades ago, that is, corporate governance in the emerging-market economies was favorably affected by financial liberalization. Competition from foreign banking and non-banking firms did exert pressure on their domestic counterparts to adopt $a$ la mode financial and banking practices as well as internationally accepted accounting standards, regulatory practices and supervision norms in the banking

${ }^{4}$ Several recent studies provide evidence to these static and dynamic effects. For instance, refer to Klenow and Rodriguez-Clare, 1997; Bekaert and Harvey, 2000; Bekaert et al, 2001; Henry, 2000a; Henry, 2000b. 
sector. Financial liberalization also promotes transparency and accountability, reducing adverse selection and moral hazard problems. These improvements in corporate government tend to reduce the cost of borrowing in the banking sector and securities markets. ${ }^{5}$ Other than promoting competition, liberalization enhances the opportunities for smoothing out the effects of real shocks. In this respect liberalization, including capital account liberalization, plays a stabilizing role. However, this line of logic has been challenged. Skeptics argued that it is not necessary that access to global capital market would increase availability of capital.

Information asymmetry is perhaps the most often cited asymmetry in the capital markets. They exist in the goods markets as well, but they are far more in number as well as more pronounced in asset markets. Due to information barriers, geographical distances and cultural differences, the problem of information asymmetry is exacerbated in the international capital markets. In addition, market imperfections of this genre are further magnified in the international capital markets due to difficulties in entering and enforcing contracts across borders. Information asymmetries do lead (and have led) to over reactions by global investors on both the sides, investing freely and withdrawing massively (Zeira, 1999). Growing globalization of capital markets and declining transaction costs can (and did) make global investors rationally "exuberant". In such an environment, information asymmetry increases the probability of herding behavior, which manifests itself in "excesses", or booms and bursts in the international capital markets (Calvo and Mendoza, 2000). Information asymmetry also generates market behavioral patterns like momentum trading, noise, trading, bandwagon effects, and short-termism.

Numerous empirical studies of the impact of financial liberalization on growth are available in the literature. Several of them have been cited below. They essentially took two routes for selecting variables to deploy and for quantifying their results. Some of them selected one proxy variable or the other for financial liberalization, while the other studies focused on specific liberalization strategies for quantifying how liberalization affected growth. Earlier empirical studies were narrow and considered the real interest rates as an adequate measure for financial repression. These studies considered the sign of the interest rates an important indicator and assumed that economies with negative real interest rates were financially repressed while those with positive real interest rates were not. These

\footnotetext{
${ }^{5}$ Some of the recent studies that bring out this point are Claessens, et al 2001; @ Galindo, et al 2001@; Moel, 2001; Mishkin, 2001.
} 
studies concluded that growth rate in economies with negative real interest rates suffered. They found that its opposite was equally true. This indicator of financial repression was subsequently rejected as inadequate and some studies adopted the ratio of credit to the private sector to GDP as a measure of financial liberalization (De Gregorio and Guidotti, 1993). Other indicators of financial development were also taken as proxies of liberalization.

After several cross-country studies with large numbers of sample countries, a gradual consensus emerged on financial development and liberalization affecting growth rate in a significantly positive manner. Deregulation creates an environment that that greatly facilitates economic growth. ${ }^{6}$ As discussed below in this section, the evidence on the benefits of financial liberalization and deregulation on real per capita GDP growth was found to be strong. Reinhart and Tokatlidid (2002) not only supported this result but also added that financial liberalization delivers a higher level of foreign direct investment (FDI) and gross capital flows. But the catch is that it occurred only in the higher income emerging markets. Financial liberalization appears to deliver financial deepening, but again in the higher income emerging markets. Economies that shunned financial repression-or more realistically dropped it at an early stage of development-and liberalized their financial sector stood a better chance of turning into emerging-market economies.

Although the general acceptability and robustness of these results was high, they need to be taken with a degree of skepticism. While they related financial liberalization with growth, they ignored other structural and macroeconomic developments that were progressing with the implementation of financial liberalization measures. Simultaneity of reform measures was a capital issues which made it difficult to isolate the effects of financial components of the reform package. While it was possible that financial liberalization played a leading role, it certainly was not the most crucial one and never the only strategy affecting growth rate in the economies being studied. Under certain circumstances, financial liberalization can have no impact on financial development at all. Emerging economies in Latin American have provided an evidence of this. Using thirty-year data from the World Development Indicators Galindo, Micco and Ordonez (2002) demonstrated that all regions experienced a significant impact on their financial systems as they liberalized. Latin American economies were an exception to this generalization. They recorded a decline in the size of their financial system during the financial

${ }^{6}$ Refer to studies by the World Bank (1989) and Roubini and Sala-I-Martin (1991). 
liberalization period in Latin America.

Empirical research focusing on specific liberalization strategies for quantifying how liberalization affected growth has not made a great deal of headway. Not many researchers have tried this route essentially because of the constraints related to liberalization data. Bekaert, Harvey and Lundblad (2002) is one of the few comprehensive cross-country studies of this kind. They took a dynamic panel of industrial and developing economies and conducted a number of empirical exercises that instill confidence in their results. They survived several econometric robustness experiments, including controlling for the global business cycle. In addition, their results were found to be robust to alternative measurements of the liberalization variable. Although their liberalization variable was a $0 / 1$ indicator, they also used a number of variables that measured the intensity and comprehensiveness of the equity market liberalization. They concluded that stock market liberalization affected growth permanently. When they augmented the standard set of variables used in economic growth research with an indicator variable for equity market liberalization, they found that liberalization of equity markets led to a one percent increase in annual real per capita GDP growth over a five-year period. This increase was found to be statistically significant. They also showed that financial liberalization increased the investment/GDP ratio and factor productivity. The one percent increase in real GDP is surprisingly large, even counterintuitive. However, it can partly be explained by the fact that equity market liberalization measures are intertwined with both macroeconomic reforms and other financial sector developments.

Indirect transmission channels between financial liberalization and growth rate have also been studied. Important among these studies is one by Laeven (2000), which took twenty-year data for thirteen emerging-market economies to conclude that liberalization process eased financial constraints, particularly those faced by large domestic firms. Results of Galindo, Schiantarelli and Weiss (2001) are important in that they inferred that financial liberalization enhances the allocative efficiency of investment. Although some of these studies have controlled for parallel on-going reforms, the simultaneity of reforms argument applies to this set of studies also because it is unclear how large were the controls. It was difficult to determine whether these controls were large enough to isolate the effects of financial liberalization.

Galindo, Micco and Ordonez (2002) addressed this issue from a cross-industrycountry panel data perspective. They improved upon Rajan and Zingales (1998) 
methodology; their approach allowed isolation of impact of financial liberalization on growth. Using time series of cross-industry-country data for 28 economies, they estimated the same empirical model as Rajan and Zingales (1998). Their inference was that financial liberalization is an instrument that under certain conditions can promote financial sector development, which in turn "can stimulate the relative growth rate of sectors that rely on external funding". However, they found that a caveat is essential, that is, for rapid growth other structural reforms that ensure proper behavior of financial markets are also essential. Financial liberalization is necessary, albeit not sufficient for rapid growth. In a fully liberalized economy, "the impact of liberalization on domestic credit market growth can be null" if regulatory and institutional support are lacking. Exposition in this section demonstrated that notwithstanding the Feldstein-Horioka puzzle and a closely related hypothesis called the home-bias, growth did occur in the emerging-market economies.

Integration with the global markets and institutions tends to speed up the reform process to achieve a resilient financial system. Summing up these arguments, one can conclude that the emerging-market economies have benefited from financial liberalization in two ways. First, by having an increased access to global pool of capital, which helped raise the level of investment and output. The second channel of benefit was improvement in the efficiency of capital allocation. Both of these are known to underpin economic growth. Despite the polemists, current drift of opinion among the international economists is towards financial liberalization and deregulation. They endorse removal of capital controls because they consider capital markets efficient. In a control free financial environment capital is likely to flow towards the most lucrative destination. The obstreperous view, that supports controls or gradual liberalization, argues that financial liberalization amounts to lurching into excesses of trans-border financial movements. This logic in the international economics literature as well as in the capital market literature is based on the view that market failures and distortions pervade capital markets around the world.

If, as stated above, a consensus has emerged on financial development and liberalization affecting growth rate in a significantly positive manner, why so many economies still have an under developed financial sector? A common, if simplistic, answer is that it is due to a lack of demand. Demand for financial development is determined by economic growth and industrialization. Or, other variables than liberalization have a decisive impact on growth. It has been observed that economies at the 
same level of development differ widely in the level of financial development. Several alternative explanations have been provided including lack of social capital necessary for financial development and weak legal, cultural and political systems. Countries with a Common Law and strong minority investor protection have better developed financial, particularly securities, markets. Structuralists also try to provide an explanation for the differences in the level of financial development. According to them, in some economies there can be real structural impediments to the development of financial sector. Once these impediments are surmounted, the supply of finance should rise to meet demand.

Experiences of the last two decades have demonstrated that financial liberalization is not risk free. It has been observed that it leads to over-borrowing. McKinnon and Pill (1999) have presented a formal framework demonstrating how and when financial liberalization may lead to bouts of overborrowing. This propensity was found to be magnified when domestic financial liberalization was undertaken along with, or a little before, capital account liberalization. As the rising levels of debts are in foreign currency, the economy soon becomes vulnerable to exchange rate fluctuations. Thus, financial liberalization becomes the cause of volatility in the capital markets.

\section{Capital Account Liberalization and Growth}

Although capital account liberalization is subsumed in financial liberalization, it has been an important issue for the emerging-market economies and deserves to be analyzed as a distinct policy move. During the last quarter century, several emergingmarket economies, that were capital-poor, permitted non-residents to participate in their domestic stock markets. In the wake of recent economic and financial crises in several emerging-market economies capital account liberalization has taken on additional importance. Some of the blame for the recent crises went to premature or poorly sequenced liberalization of capital account, which has been dealt with below.

Over the years, two broad views have emerged regarding how capital account liberalization affected an economy, particularly the financial sector. The allocative efficiency view is the older one and better debated of the two. To state it briefly, when capital account barriers on the flow of capital are removed, trans-border capital movements begin. Capital tends to move from capital-abundant economies, where marginal rate of return is lower, to capital-scarce economies where marginal 
rate of return is rationally expected to be higher. In the latter country group, the cost of capital declines which in turn favorably impacts investment and output (Fischer, 1998; Stulz, 1999; Mishkin, 2001).

The newer view was put forward by Rodrik (1998) and Stiglitz (2000a and 2000b). It was christened the "animal spirit" and treated the older view of the impact of capital account liberalization simplistic, if not downright fanciful. The proponents of this view, as opposed to the old one, believe that capital account liberalization does not result in efficient allocation of financial resources because international capital movements have little connection with real economic activity in the host economies. They posited that capital account liberalization has no impact on domestic investment, output or any real variable with non-trivial welfare implications.

Opening the stock markets for non-residents comprises a discrete change in the degree of capital account openness. As several emerging-market economies liberalized their capital accounts and allowed non-residents to purchase shares in their stock markets, statistical data to empirically examine the two abovementioned hypotheses regarding the impact of capital account liberalization are readily available. Allocative efficiency hypothesis can be tested in two ways with the help of time series data for the prices and quantities of capital during the liberalization period (Chari and Henry, 2002). The first method could be to examine whether cost of capital has been driven down and Tobin's $q$ has been driven up by the inflows of global capital after the liberalization of capital account. Before proceeding further, we must be clear about what is implied by Tobin's q. It stands for the asset market value of installed capital goods relative to their replacement cost. The second testing method could be that profit-maximizing firms may respond to rising level of Tobin's q by increasing investment in physical capital. This increase in the level of investment would continue until the asset market value of capital goods and their replacement costs are equalized. If the allocative efficiency hypothesis is correct, data should reveal a temporary increase in Tobins q as well as in investment after capital account is liberalized. However, if the animal spirit view of things is correct, there should be no discernible increase in prices and quantity of capital inflows during the liberalization episode.

Chari and Henry (2002) made time series and cross-sectional estimates on data for 1980-94 period for 369 firms in India, Jordan, Korea, Malaysia, and Thailand and found that time series results were more consistent with allocative efficiency hypothesis than with animal spirit hypothesis. They concluded that a typical firm 
does experience both an increase in Tobin's q and investment during the liberalization episode. For their sample firms they found that during the year capital market was liberalized, the growth rate of capital stocks exceeded their pre-liberalization mean by 4.1 percent. During the next three years the average growth rate of capital stock for the 369 firms in the sample exceeded its pre-liberalization mean by 6.1 percent. As opposed to this, cross-sectional estimates were found to be more consistent with animal spirits hypothesis. Same or similar results were arrived at by other recent studies. For instance, Bekaert and Harvey (2000) and Henry (2000a and 2000b) provided evidence of capital market and stock market liberalization leading to higher stock prices and more investment in the economy. Conversely, Rodrik (1998) provided evidence from aggregate cross-sectional data of no significant relationship between the investment/GDP ratios in the sample economies and openness of capital account, supporting the animal spirit hypothesis.

These results need to be carefully interpreted. The two sets of results suggest that neither of the two hypotheses provide a completely accurate view of the impact of liberalization of capital account. Although liberalization of capital account may encourage the movement of capital from capital-abundant to capital-scarce economies, only this policy measure is certainly not enough to ensure efficient allocation of productive capital between firms and sectors. In addition, in the empirical argument related to Tobins q, the conclusion is mixed, in that improvement in allocative efficiency is supported by time-series analysis but neglected by cross-section analysis. From an econometric standpoint, this implies that the allocative efficiency hypothesis is not supported in the long run, but it is supported in the short-run. Thus, the Tobins q logic provides only a weak support to the enhancement in allocative efficiency hypothesis.

\section{Capital Account Liberalization and Volatility}

Capital account is liberalized by removing statutory restrictions on cross-border global capital flows, which in turn is an important facet of general financial liberalization. It entails relaxation or removal of controls on transactions in the capital and financial accounts of the balance-of-payments. One of the most important removals of restriction is on the convertibility of foreign exchange. Macroeconomic and financial volatility are a well-known downside effect of financial liberalization. Capital account liberalization is frequently blamed for causing both the kinds of volatility noted above. Capital account liberalization 
leads to exposure to credit risk and foreign exchange risk rises. As alluded to earlier, in the early 1970s, the emerging-market economies of Western Hemisphere liberalized to end their much-criticized financial repression. Soon these economies found themselves in the midst of macroeconomic crises and hoards of bankruptcies. After the emerging market financial crises of the 1990s and early 2000s - which claimed a good number of emerging-market economies as their victims - this characteristic of financial market liberalization acquired a new significance.

Kaminsky and Reinhart (1999) have established a link between financial liberalization and economic, financial and balance-of-payments crises. All of these crises were traumatic and had high economic and social costs. The economic logic behind these crisis, namely over-borrowing and over-lending, has been discussed in Section 4. The individual emerging-market economies suffered as much as the global economy. The emerging-market economies of East and Southeast Asia had successfully established their reputation as high performers. In 1997, several of them succumbed to their worst recessions in decades. The global banking and financial system was also adversely affected during several occasions during this period. Global capital market flows to emerging-market economies, which were booming in the early and mid-1990s, declined to a trickle by 1997 and 1998. Until 2002, capital markets flows to emerging-market economies in the form of bank lending, bond lending, equity flows and other flows had not recovered, although foreign direct investment (FDI) had held firm.

An important casualty of these crises was the rising trend towards financial liberalization, both at the domestic and global tiers. Opinion leaders like Paul Krugman (1998) and Joe Stiglitz (1999) began opposing financial liberalization and supporting restrictive global capital flows. ${ }^{7}$ They began to blame unrestricted trans-border capital flows for disorderly, if on occasion totally erratic, capital market behavior, both domestically and globally. Their logic was that restrictions on global capital flows would help in moderating "excessive boom-burst" pattern in financial markets so prevalent in the 1990s and early 2000s. Krugman (1998) even suggested controls on capital outflows, which sounded like an archaic notion. ${ }^{8}$ In the early 1970s, this and similar propositions were opposed as inefficient and

\footnotetext{
${ }^{7}$ Results of several empirical studies can be cited for this purpose. For instance, refer to Ghani (1992), King and Levine (1993), Levine, Jayaratna and Strahan (1996); Loayza and Beck (1999) and Beck, Levine, and Loayza (2000).

${ }^{8}$ Paul Krugman strongly supported Malaysias adoption of capital controls in 1998. Other economists who proposed limiting capital flows included Rodrik (1998).
} 
counter productive. Indiscriminate advocacy of greater financial liberalization and development virtually stopped. Saving grace behind the proposals of restrictions over capital flows was that they were more of less intended for a short-term, for the purpose of handling a crisis situation and for obstructing disorderly retreat of global investors in a crisis-ridden economy. As a permanent policy measure, these proposals did not win many supporters.

Distortionary macroeconomic policies and macroeconomic volatility have been found to be closely related. Inapt macroeconomic policies like excessive government spending, high inflation, over-valued exchange rate render an economy prone to crisis. Demirguc-Kunt and Detriagiache (1998) blamed macroeconomic and financial instability on the lack of institutional development in an economy. It is common that institutions needed for financial regulation and supervision take time to develop, and once developed they go into action slowly. The likelihood of financial crisis in the wake of financial liberalization declines with the rising level of institutional development. Creating and strengthening institutions is the task of the governments. Thus, government intervention in the system in the form of (a) institutional development, (b) prudential regulation in the banking and non-banking financial sectors and (c) supervision in these very sectors has a convincing justification. At least in the early stages, governments in the emerging-market economies need to ensure proper functioning of the financial system and therefore intervene more than in the later stages when these developments have made a reasonable progress. If regulation and supervision in the financial sector progress hand in hand with financial liberalization, the negative impact of financial liberalization on the emerging market economy can be reined in (Das, 2002).

In the early stages, liberalization can have a destabilizing effect over the financial sector because it abruptly increases the exposure to credit risk and foreign exchange riska fortiori when liberalization is undertaken in an environment of macroeconomic stability. In a newly liberalized financial environment, managers lack the experience to manage the two risks named earlier and have a tendency to push towards riskier investments. In such a financial environment even soundly managed banks feel it to be a good strategy to build up large open foreign positions abroad to finance domestic assets, or to engage in foreign exchange lending to domestic residents. As stated in the preceding paragraph, this situation calls for government intervention and strengthening of regulatory and supervisory framework. 


\section{Degree of Liberalization on Global Ownership of Equities}

Quantifying the degree of capital account liberalization is not considered an easy exercise. Therefore, there was a predominance of qualitative measures of liberalization. They largely build on the comprehensive, country-wise, data and information annually compiled by the International Monetary Fund (IMF) and published in the Annual Report on Exchange Arrangements and Exchange Restrictions. This publication documents rules, and annual changes in them, regarding restrictions or liberalization of capital inflows in the IMF member economies. This documentation does not provide any indication of the intensity of capital controls. Its frequency of data is also low. Some recent empirical studies have tried to score the intensity of capital controls (Quinn, 1997). Recent finance literature treats capital account liberalization as either one-time events or structural breaks, although both of these approaches need refinement (Edison and Warnock, 2001).

When capital account liberalization is treated as either one-time events or structural breaks, the general assumption is that all episodes of liberalization are comparable and that they have equal intensity and pace. It does not have to be so. In reality, each economy is sui generis in this regard and has its own intensity and pace of capital account liberalization. The factors responsible for differences in the pace and modes of liberalization are historic, economic and political. Besides, the stage of economic development, priorities of the government and the perception and acumen of the policy makers explain the differing paces of liberalization. Liberalization measures take may different forms. Some are partial while others are complete, some are one-time events other are gradual dénouement. For instance, in the emerging economies of Western Hemisphere liberalization was much faster than that in those of Asia. It was closer to the one-time event scenario and launched earlier than in Asia. Measuring the intensity of liberalization with the help of the annual measures of capital controls formed with the help of dummy variables is not helpful because it hardly provides any indication of the intensity of capital controls.

A measure that takes into account both the intensity of controls and has higher frequency than annual for the emerging-market economies and other economies. Edison and Warnock (2001) devised a monthly measure of the intensity of controls for a liberalizing economy, which is simple to construct. It also calibrates the intensity of controls at a point in time (or the static view) as well as their evolution 
through time (or the dynamic view). Their monthly measure is based on the International Finance Corporation (IFC) data. It is the ratio of the market capitalizations underlying a countys Investable and Global indices as computed by the IFC. The IFC has been calculating these two indices for the emerging-market economies for some time. The Global index (IFCg) is designed to represent the market, while the Investable index (IFCi) represents the portion of the market available to the global investors. Thus, the ratio of market capitalizations of an emerging market economys IFCi and IFCg indices is a quantitative measure of the availability of the economy's equities to global investors. One minus the ratio becomes a measure of the intensity of capital controls.

$$
\text { Intensity of Capital Controls }=1-\frac{\mathrm{IFCi}}{\mathrm{IFCg}}
$$

These IFC data were available for a long time (since December 1988) but they attracted the attention of only a few researchers. Empirical research did not adequately use them. Another version of this measure was used by Bachatta and van Wincoop (2000) to conclude that in general liberalization in the emerging economies appeared to be gradual. It was also not followed up by other empirical studies as a viable measure of capital controls. Chari and Henry (2001) used firmlevel IFC data to examine the salient features of firms in which global investors tend to invest, and the firms in which they choose not to invest. One weakness of the measure devised by Edison and Warnock (2001) is that it is narrow, because it only focuses on global ownership of domestic equities. The flip side of this coin is that it is readily available at high (monthly) frequency, starting in 1988 for all the emerging-market economies. Its lends itself to empirical analysis of cross-sectional and time-series data sets. The fact that it is based on the rich IFC database makes this measure easy to compile. ${ }^{9}$

\section{Liberalization of Equity Markets and Volatility}

During the recent episodes of crisis in the emerging-market economies, stock markets displayed an excessive boom-burst behavior. The economic logic of

${ }^{9}$ Until the end of 1999, the IFC published these data series. Thereafter, in January 2000 Standard and Poors took over the ownership of the IFCs price indices. 
excessive volatility of stock markets is partly the same as explained in Section 4. Many asked the question, "Did liberalization of the equity market cause it?" To answer the question whether liberalization of equity markets triggered recent spate of financial excesses and crises in the emerging-market economies, Kaminsky and Schmukler (2002) examined the possible time-varying pattern of financial cycles before and after financial liberalization in 28 emerging market and industrial economies since 1973. They focused on the duration of upturns and downturns in financial markets, and the magnitude of cycles, taking into account the fact that characteristics of stock market cycles have changed over time. They compared the characteristics of these cycles during episodes of repression and financial liberalization.

Kaminsky and Schmukler (2002) answered the rhetorical question raised above in a negative manner. They took into account the financial crises in the emerging and industrial economies, including the crises of the 1990s, before concluding that financial cycles in the equity markets were not intensified by financial liberalization. If anything, the opposite is the truth. Equity market cycles become smoother after liberalization. Interestingly they found inter-temporal differences in the impact of financial liberalization over the equity market. Liberalization tended to trigger more explosive financial cycles in the immediate aftermath of financial liberalization. However, in four years after liberalization the equity market volatility became markedly less pronounced. This observation applies to both emerging-market economies as well as the matured industrial economies.

In this scheme of things, integration of domestic equity markets in the emergingmarket economies with the global financial markets contributes to a decline in domestic equity market volatility. The expectations of non-resident investors have something to do with this development. Better skills and information enable the non-resident investors to monitor the management of firms in which they are purchasing stocks. Before liberalization, the domestic investors were unable to do so because they did not have this capability. Equity market liberalization also allows domestic firms, at least the large ones, to access matured capital markets for capital. When firms list on the large global bourses, they find themselves within the jurisdictions of a superior legal system than the one they had at home. They need to become more transparent and respond to higher information disclosure standards of their new hosts. During the 1990s and early 2000s a good number of firms from the emerging-market economies, particularly from the Asian and Latin American emerging-market economies, began to list on foreign stock markets. These 
developments and new institutional norms tend to attenuate "excessive" financial cycles. In addition, as this kind of two-way expansion and diversification progresses, equity markets in the emerging-market economies become less sensitive to actions of single large investors, which also dampens the tendency towards equity market volatility.

\section{Conclusions and Summary}

Although financial Liberalization and growth nexus has been extensively studies by economists of differing hues, there were several difficulties in establishing a direct link. It is only one of the several factors that contribute to growth. Early studies of scholars like Goldsmith, McKinnon and Shaw considered this link to be a direct, simple and positive one. It worked by strengthening the size and improving the efficiency of the domestic financial system, by allowing domestic firms to access the global financial markets, and by improving the level of corporate governance in the domestic financial system and thereby reducing the agency problems.

This scenario has been studied and refined by including static and dynamic factors. A good deal of evidence was provided by several emerging-market economies regarding foreign competition promoting in the domestic banking and non-banking financial sectors, reducing cost of capital. Also, when domestic firms begin accessing the global capital market, their cost of capital declines and raises the level of domestic investment. There can be little doubt that there are static and dynamic impacts of these developments. Efficiency of capital allocation by markets improves and financial resources head for sectors having comparative advantage that were constrained during the period of financial repression tress growth rate. Recent studies have also supported what McKinnon and Shaw posited three decades ago, that is, corporate governance in the emerging-market economies was favorably affected by financial liberalization. Financial deregulation and reforms fuels institutional reforms. Integration with the global markets and institutions tends to speed up the reform process to achieve a resilient financial system. Thus, liberalized emerging markets came to have an opportunity to grow and develop like their counterparts in the advanced industrial economies. However, this line of logic has been challenged.

A gradual consensus has now emerged on financial development and liberalization affecting growth rate in a significantly positive manner. Deregulation creates 
an environment that that greatly facilitates economic growth. Evidence on the benefits of financial liberalization and deregulation on real per capita GDP growth was found to be strong. But it was possible that financial liberalization played a leading role, it certainly was not the most crucial one and never the only strategy affecting growth rate.

Two clear and opposing views emerged regarding how capital account liberalization affects an economy, particularly the financial sector. The allocative efficiency view holds that when capital account barriers on the flow of capital are removed, trans-border capital movements begin. Capital tends to move from capitalabundant economies, where marginal rate of return is lower, to capital-scarce economies where marginal rate of return is expected to be higher. The newer view was christened the "animal spirit" and treated the older view of the impact of capital account liberalization simplistic, if not downright fanciful. The proponents of this view believe that capital account liberalization does not result in efficient allocation of financial resources because international capital movements have little connection with real economic activity. However, most empirical studies concur with the allocative efficiency hypothesis.

It was believed that capital account liberalization leads to vaoltility, which led to a support for restrictive global capital flows. The unrestricted trans-border capital flows were blamed for disorderly, if on occasions totally erratic, capital market behavior, both domestically and globally. Their logic was that restrictions on global capital flows would help in moderating "excessive boom-burst" pattern in financial markets so prevalent in the 1990s and early 2000s. An important result of this view was that financial market liberalization and reforms slowed down. However, as a permanent policy measure, these proposals for not liberalizing the capital account did not win many supporters.

During the recent episodes of crisis in the emerging-market economies, stock markets displayed an excessive boom-burst behavior. Some believed that it was the liberalization of equity markets, which was to be blamed for their volatility. Empirical studies showed that the equity markets volatility was not intensified by financial liberalization. If anything, the opposite is the truth. Equity market cycles become smoother after liberalization. Interestingly they found inter-temporal differences in the impact of financial liberalization over the equity market. Liberalization tended to trigger more explosive financial cycles in the immediate aftermath of financial liberalization. However, in four years after liberalization the equity market volatility became markedly less pronounced. In this scheme of 
things, integration of domestic equity markets in the emerging-market economies with the global financial markets contributes to a decline in volatility.

Received 29 May 2003, Accepted 22 October 2003

\section{References}

Bachatta, P. and E.van Wincoop. (2000). "Capital Flows to Emerging Markets: Liberalization, Overshooting, and Volatility" in S. Edwards (ed) Capital Flows and Emerging Economies. Cambridge. MA. National Bureau of Economic Research and the University of Chicago.

Beck, T., R. Levine, and N. Loayza. (2000). "Finance and Sources of Growth", Journal of Financial Economics, Vol. 58. No. 1. pp. 261-300.

Bekaert, G. and C.R. Harvey. (2000). "Foreign Speculators and Emerging Equity Markets", Journal of Finance, Vo. 55. No. 2. pp 565-614.

Bekaert, G., C.R. Harvey and C. Lundblad. (2002). "Does Financial Liberalization Spur growth?" paper presented at the joint conference between the World Bank and George Washington University on Financial Globalization: A Blessing or A Curse? held on May 30-31, 2002, in Washington DC.

Calvo, G. and E. Mendoza. (2000). "Capital Market Crisesand Economic Collapse in Emerging Markets: an Informational-Frictions Approach", American Economic Review, Papers and Proceedings, Vol. 90. pp. 59-70.

Chari, A. and P.B. Henry. (2001). "Stock Market Liberalization and the Repricing of systemic Risk". Cambridge. MA. National Bureau of Economic Research. NBER Working Paper No. 8265.

Claessens, S., A. Demirguc-Kunt and H. Huizinga. (2001). "How Does Foreign Entry Affect Domestic Banking Markets?” Journal of Banking and Finance. Vol. 25. No. 4. pp. 891-911.

Chari, A. and P.B. Henry. (2002). "Capital Account Liberalization: Allocative Efficiency or Animal Spirit? paper presented at the joint conference between the World Bank and George Washington University on Financial Globalization: A Blessing or A Curse? held on May 30-31, (2002), in Washington DC.

Das, Dilip K. 2002. "Managing Financial Markets and Exchange Rate Volatility Arising from Globalization", Global Business \& Economic Review, December 2002. pp.

De Gregorio, J. and P. Guidotti. (1993). "Financial Development and Economic Growth", Washington DC. International Monetary Fund. July.

Demirguc-Kunt, A. and E. Detriagiache. (1998). "Financial Liberalization and Financial fragility”, Washington DC. International Monetary Fund. IMF Working Paper No. WP 98/83.

Eichengreen, B. (2002). "Capital Account Liberalization: What Do the Cross-Country Studies Tell Us?" World Bank Economic Review, March. Vol. 22. No. 2. pp. 177-208. 
Fischer, S. (1998). "Capital Account Liberalization and the Role of the IMF", Essays in International Finance. No. 207. Princeton, NJ. Princeton University Press. pp. 1-10.

Galindo, A., F. Schiantarelli and A. Weiss. (2001).'Does Financial Liberalization Imprgve the Allocation of Investment?", Washington DC. Inter-American Development Bank. (mimeo)

Galindo, A., A. Micco and G. Ordonez. (2002). "Financial Liberalization and Growth: Empirical Evidence", paper presented at the joint conference between the World Bank and George Washington University on Financial Globalization: A Blessing or A Curse? held on May 30-31, (2002), in Washington DC.

Ghani, E.1992. "How Financial Markets Affect Long-Term Growth: A Cross-Country Study", Washington DC. World Bank. Policy Research Working Paper No. WPS 843.

Gilchrist, S. and C. Himmelberg. (1998). Investment Fundamentals and Finance, NBER Macroeconomic Annual. Cambridge. MA. The MIT Press.

Goldsmith, R. (1969). Financial Structure and Development, New haven. CT. Yale University Press.

Henry, P. B. (2000a). "Stock Market Liberalization, Economic Reforms and Emerging Market Equity Prices", Journal of Finance, Vol. 58. No. 1-2. pp. 301-34.

Henry, P. B. (2000b). "Does Market Liberalization Cause Investment Booms", Journal of Finance and Economics, Vol. 55. No. 2. pp. 529-563.

Hubbard, G. (1998). "Capital Market Imperfections and Investment", Journal of Economic Literature, Vol. 36. No. 3. pp. 193-225.

Jayaratna, J. and P.E. Strahan. (1996). "The Finance-Growth Nexus: Evidence from bank Branch Deregulation”. Quarterly Journal of Economics, Vol. 111. No.3. pp. 639-570.

Kaminsky, G.L. and C. Reinhart. (1999). "The twin Crises: The Causes of Banking and Balance of Payments Problems", American Economic Review. Vol. 89. No. 3. pp. 473-500.

Kaminsky, G.L. and S.L. Schmukler. (2002). "Short-Run Pain, Long-Term Gain: the Effects of Financial Liberalization", paper presented at the joint conference between the World Bank and George Washington University on Financial Globalization: A Blessing or A Curse? held on May 30-31, 2002, in Washington DC.

King, R. and R. Levine. (1993). "Finance and Growth: Schumpter Might Be Right", Quarterly Journal of Economics, Vol. 108. No. 3. pp. 717-737.

Klenow, P. and A. Rodriguez-Clare. (1997). "Economic Growth: A Review Essay" Journal of Monetary Economics, Vol. 40. No. 3. pp. 597-617.

Krugman, P. (1998). "Saving Asia: Its Time to Get Radical", Fortune, September 7, pp. 74-80.

Laeven, L. (2000). "Does Financial Liberalization Reduce Financial Constraints?' Washington DC. World Bank. Policy Research Working Paper No. 2435.

Levine, R., N. Loayza and T. Beck. (1999). "Financial Intermediation and Growth: Causality and Causes". Washington DC. World Bank. Policy Research Working Paper No. 2400 . 
McKinnon, R.I. (1973). Money and Capital in Economic Development, Washington DC. The Brookings Institution.

McKinnon, R.I. and H. Pill. (1999). "Credible Economic Liberalization and Overborrowing", American Economic Review, Vol. 89. No. 2. 187-93.

Mishkin, F. (2001). "Financial Policies and the Prevention of Financial Crises in Emerging Market Countries", Cambridge. MA. National Bureau of economic Research. NBER Working Paper No. 8087.

Moel, A. (2001). "On American Depository Receipts and Emerging Markets", Economica. Vol.2, No. 1. pp 209-273.

Quinn, D. (1997). "The Correlates of Changes in International Financial Regulations". American Political Science Review. Vol.91. No. 3. pp. 531-51.

Rajan, R. and L. Zingales. (1998). "Financial Dependance and Growth" American Economic Review, Vol. 88. No.3. pp. 559-586.

Reinhart, C.M. and I. Tokatlidid. (2002). Paper presented in the conference on Financial Globalization: A Blessing or A Curse, joint conference organized by the George Washington University and the World Bank, on 30-31 May, in Washington DC.

Rodrik, D. (1998). "Who Needs Capital Account Convertibility?" Princeton Essays in International Finance. No. 207. Princeton, NJ. Princeton University Press. pp. 55-65.

Roubini, N. and X. Sala-I-Martin. (1991). "Financial Development, the Trade Regime and Economic Growth", Cambridge, MA. National Bureau of Economic Research. NBER Working Paper No. 3876.

Sachs, J. D. and A.M. Warner. (1995). "Fundamental Sources of Long-Run Growth", American Economic Review, Papers and Proceedings. Vol. 85. May. pp. 122-134.

Sarkissian, S. and M. Schill. (2001). "The Overseas Listing Decisions: New Evidence of Proximity Preference. (mimeo)

Shaw, E. (1973). Financial Deepening in Economic Development, New York. Oxford University Press.

Stiglitz, J. (1999). "Bleak Growth for the Developing World", International Herald Tribune, April 10-11. p.6.

Stiglitz, J. (2000). "What I Learned at the World Economic Crisis", The New Republic, April 17. pp. 56-60.

Stulz, R.M. (1999). "International Portfolio Flows and Security Markets" in M. Feldstein (ed) International Capital Flows, Chicago. University of Chicago Press.

Williamson, J. and M. Mahar. (1998). “A Survey of Financial Liberalization”, Essays in International Finance, No. 211. November. Princeton. Princeton University Press.

World Bank. (1989). "World Development Report 1989”, New York. Oxford University Press for the World Bank.

Zeira, J. (1999). "International Overshooting, Booms and Crashes", Journal of Monetary Economics, Vol. 43. No. 2. pp. 237-257. 